\title{
Large plexiform neurofibroma of the lower extremity
}

\section{Mohammed Chaouche, Younes Barbach, Abdellah Dah Cherif, Sara Elloudi, Hanane Baybay, Fatima Zahra Mernissi}

Department of Dermatology and Venereology, University Hospital Hassan II, Fez, Morocco

Corresponding author: Dr. Mohammed Chaouche, E-mail: medch11@hotmail.com

33-year-old female patient with a paternal family history of neurofibromatosis type 1 and a large plexiform neurofibroma of her right lower extremity present (Fig. 1). He was no longer able to wear normally, which in turn affected his activities of daily living.

Plexiform neurofibroma is an uncommon variant of neurofibroma, a benign tumor of peripheral nerves

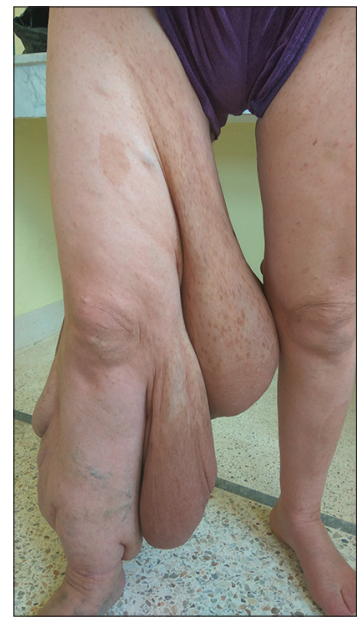

Figure 1: Large plexiform neurofibroma of the lower extremity.
(WHO grade I) [1], arising from a proliferation of all neural elements. Plexiform neurofibromas are essentially pathognomonic of neurofibromatosis type 1 (NF1). Unlike small sporadic localized neurofibromas and diffuse cutaneous neurofibromas, these tumors are at a significant risk of eventual malignant [2].

\section{Consent}

The examination of the patient was conducted according to the Declaration of Helsinki principles.

\section{REFERENCES}

1. Kleinhues P, Cavenee WK. Tumours of the nervous system. In World Health Classi-cation of Tumours. Lyon: IARC Press Lyon; 2000.

2. Huson SM, Hughes RA. The Neuro-bromatosis: A Pathogenetic and Clinical Overview. London: Chapman and Hall Medical; 1994

Copyright by Mohammed Chaouche, et al. This is an open-access article distributed under the terms of the Creative Commons Attribution License, which permits unrestricted use, distribution, and reproduction in any

medium, provided the original author and source are credited.

Source of Support: Nil, Conflict of Interest: None declared.

How to cite this article: Chaouche M, Barbach Y, Cherif AD, Elloudi S, Baybay H, Mernissi FZ. Large plexiform neurofibroma of the lower extremity. Our Dermatol Online. 2019;10(e):e16.1.

Submission: 23.01.2019; Acceptance: 25.03.2019

DOI: 10.7241 /ourd.2019e.16 